\title{
ANTIMICROBIAL, ANTIRADICAL AND INSECTICIDAL ACTIVITY OF GARDENIA GUMMIFERA L. F. (RUBIACEAE)
}

\author{
PRASHITH KEKUDA T. R. ${ }^{1}$, RAGHAVENDRA H. L.. ${ }^{*}$, SHILPA M. ${ }^{1}$, PUSHPAVATHI D. ${ }^{1}$, TEJASWINI PETKAR ${ }^{1}$ \\ AYESHA SIDDIQHA ${ }^{1}$
}

1Department of Microbiology, S. R. N. M. N College of Applied Sciences, N. E. S Campus, Balraj Urs Road, Shivamogga 577201, Karnataka, India, 'Department of Biochemistry, School of Medicine, Wollega University, P. 0. Box: 395, Nekemte, Ethiopia

Email: raghu.biogem@gmail.com

Received: 26 May 2017 Revised and Accepted: 31 Aug 2017

\section{ABSTRACT}

Objective: The present study was carried out to investigate antimicrobial, antiradical and insecticidal potential of leaf and fruit of Gardenia gummifera L. f. (Rubiaceae).

Methods: The leaf and fruits were shade dried, powdered and extracted by maceration process using methanol. Antibacterial activity was evaluated against Gram positive and Gram negative bacteria by Agar well diffusion assay. Antifungal activity was determined against six seed-borne fungi by Poisoned food technique. Antiradical activity of leaf and fruit extracts was evaluated by 1,1-diphenyl-2-picrylhydrazyl (DPPH) and 2,2-azinobis 3ethylbenzothiazoline 6-sulfonate (ABTS) radical scavenging assays. Insecticidal activity of leaf and fruit extracts, in terms of larvicidal and pupicidal activity, was assessed against larvae and pupae of Aedes aegypti.

Results: Both the extracts inhibited all test bacteria. Marked antibacterial activity was displayed by fruit extract when compared to leaf extract. $S$. epidermidis and E. coli were inhibited to highest and least extent by both extracts respectively. Fruit extract was found to exhibit higher antifungal effect when compared to leaf extract. Leaf extract and fruit extract exhibited highest inhibitory activity against A. niger and A. flavus respectively. Leaf and fruit extracts scavenged DPPH radical's dose dependently with an $\mathrm{IC}_{50}$ value of $49.01 \mu \mathrm{g} / \mathrm{ml}$ and $2.53 \mu \mathrm{g} / \mathrm{ml} \mathrm{respectively.} \mathrm{The} \mathrm{scavenging} \mathrm{of}$ ABTS by leaf and fruit extracts was dose dependent and the $\mathrm{IC}_{50}$ value for leaf and fruit extract was $2.58 \mu \mathrm{g} / \mathrm{ml}$ and $2.31 \mu \mathrm{g} / \mathrm{ml}$ respectively. Fruit extract was shown to exhibit marked antiradical activity when compared to leaf extract. Leaf and fruit extracts exhibited dose dependent insecticidal activity in terms of larvicidal and pupicidal activity and the susceptibility of larvae and pupae to extracts was in the order II instar larvae>IV instar larvae>pupae. Fruit extract displayed marked insecticidal potential when compared to leaf extract.

Conclusion: Overall, fruit extract of G. gummifera exhibited marked antimicrobial, antiradical and insecticidal activity when compared to leaf extract. The plant can be used for developing agents/formulations effective against infectious microorganisms, oxidative stress and insect vectors that transmit dreadful diseases. The observed bioactivities could be ascribed to the presence of active principles which are to be isolated and characterized.

Keywords: Gardenia gummifera L. f., Agar well diffusion, Poisoned food technique, DPPH, ABTS, Insecticidal, Aedes aegypti

(C) 2017 The Authors. Published by Innovare Academic Sciences Pvt Ltd. This is an open access article under the CC BY license (http://creativecommons.org/licenses/by/4.0/) DOI: http://dx.doi.org/10.22159/ijpps.2017v9i10.20252

\section{INTRODUCTION}

The family Rubiaceae is one among the largest families of angiosperms and includes important plant genera such as Coffea, Cinchona and Gardenia. The genus Gardenia belongs to the family Rubiaceae and has a number of species distributed in tropical and subtropical regions of the world. Several species of Gardenia are known to be medicinally important and have been used in various systems of traditional medicine. Some species yield wood which can be used as substitute for boxwood. It is also a component of certain perfumes [1, 2]. Gardenia gummifera L. f. is found distributed in different states of India namely Uttar Pradesh, Tamil Nadu, Karnataka, Kerala, Maharashtra, Bihar and Andhra Pradesh. It is called Naadi-hingu and Dikamali in Ayurveda and Tikkamalli in Sidda, Gummy Cape Jasmine in English and Bukki gida or Kaatu hingu in Kannada. It is a small sized, unarmed, deciduous shrub with yellow resinous buds. Leaves are sessile, ovate, ellipiticoblong or obovate, obtuse or subacute at apex. Flowers are terminal, large and 1-3 together. Calyx is up to $1 \mathrm{~cm}$ long and pubescent. Corolla tube is $2.5-5.0 \mathrm{~cm}$ long, white, turning yellow in the evening. Fruit is a berry, ellipsoid or oblong, up to $4 \mathrm{~cm}$ long, striate, crowned with persistent calyx $[3,4]$.

Dikamali is the gum resin obtained from the leaf buds of G. gummifera. This resin is claimed to possess medicinal properties such as anthelmintic, antispasmodic, carminative, diaphoretic, expectorant, and cardiotonic [5]. The plant has been used as traditional medicine in various parts of India to treat ailments such as haemorrhoids, bone fracture, nervous disorders, diarrhea, wounds, skin diseases and stomach ulcers [6-13]. G. gummifera is shown to exhibit various bioactivities such as antioxidant [14-16], antimicrobial [8, 17], insecticidal [18], Cytotoxic [19], hepatoprotective [20], antihyperlipidemic [21], anti-atherogenic [22], antiulcer [15], cardioprotective [23], analgesic [14], anti-inflammatory [14], antipyretic [14], and anthelmintic activity [14]. The present study was carried out to investigate antiradical and insecticidal activity of extract obtained from leaf and fruit of G. gummifera.

\section{MATERIALS AND METHODS}

Chemicals and media

Chemicals viz. DPPH and ABTS were purchased from Sigma Chemical Co., USA. Chemicals namely methanol, ascorbic acid, potassium persulfate, dimethyl sulfoxide (DMSO) and chloramphenicol and media namely Nutrient agar, Nutrient broth and Potato dextrose agar were purchased from HiMedia, Mumbai, India.

\section{Collection and identification of plant}

The plant samples were collected from Kavalegudda, which is about $7 \mathrm{~km}$ away from Sagara, Shivamogga district, Karnataka during February 2017. The plant was identified on the basis of its characteristics by referring standard flora [4] and with the help of taxonomist Dr. Vinayaka K. S, Assistant Professor, KFGC, Shikaripura, Shivamogga district, Karnataka, India. A voucher specimen 
(SRNMN/PK/Gg-01) was deposited in the department herbaria for future reference.

\section{Extraction}

The leaves and fruits were separated, washed well using clean water, dried under shade and powdered. Extraction of powdered leaf and fruit $(10 \mathrm{~g})$ was carried out by maceration process using methanol $(100 \mathrm{ml})$ in separate stoppered containers. The powders were left in methanol in stoppered containers for $48 \mathrm{~h}$ and the containers were stirred frequently. The contents were filtered through Whatman No. 1 filter paper and the filtrates were evaporated to dryness to get crude leaf and fruit extracts. The extracts were stored in refrigerator until use [24].

\section{Test bacteria}

Gram positive bacteria (Staphylococcus aureus NCIM 5345, Staphylococcus epidermidis NCIM 2493, Bacillus subtilis NCIM 2063 and Bacillus cereus NCIM 2016) and Gram negative bacteria (Escherichia coli NCIM 2065, Pseudomonas aeruginosa NCIM 2200 and Salmonella typhimurium NCIM 2501) were used to assess their susceptibility to leaf and fruit extract of G. gummifera. The test bacteria were procured from National Chemical Laboratory (NCL), Pune, India.

\section{Antibacterial activity of leaf and fruit extracts}

The potential of leaf and fruit of G. gummifera to inhibit bacteria was determined by Agar well diffusion method. $24 \mathrm{~h}$ old Nutrient broth cultures of test bacteria were swab inoculated on sterile Nutrient agar plates. Using a sterile cork borer, wells of $8 \mathrm{~mm}$ diameter were punched in the inoculated plates. Respective wells were filled with $100 \mu \mathrm{l}$ of leaf and fruit extracts $(20 \mathrm{mg} / \mathrm{ml}$ of DMSO), standard antibiotic (Chloramphenicol; $1 \mathrm{mg} / \mathrm{ml}$ of sterile distilled water) and DMSO. The plates were incubated in upright position for $24 \mathrm{~h}$ at 37 ${ }^{\circ} \mathrm{C}$ and zones of inhibition formed around wells were measured [25].

\section{Test fungi}

Six seed-borne fungi (isolated previously from moldy grains of sorghum) namely Aspergillus niger, A. flavus, A. fumigatus, Curvularia sp., Alternaria sp. and Fusarium sp. were screened for their susceptibility to leaf and fruit extract of G. gummifera.

\section{Antifungal activity of leaf and fruit extracts}

Poisoned food technique was employed to evaluate antifungal potential of leaf and fruit extracts. In brief, well sporulated cultures of test fungi were inoculated on control plates (without extracts) and poisoned potato dextrose agar (1 $\mathrm{mg}$ extract $/ \mathrm{ml}$ of medium) plates aseptically. The plates were incubated for $96 \mathrm{~h}$ at room temperature in upright position and the diameter of fungal colonies in mutual perpendicular directions was measured. The inhibition of mycelial growth of test fungi (\%) by leaf and fruit extracts was determined using the formula:

$$
\text { Inhibition of Mycelial Growth (\%) }=\frac{(\text { Control }- \text { Test })}{\text { Control }} \times 100
$$

Where control and test denotes the colony diameter of test fungi on control and poisoned plates respectively [25].

\section{Antiradical activity of leaf and fruit extracts}

We screened antiradical potential of leaf and fruit extracts of $G$. gummifera by two in vitro assays namely DPPH radical scavenging activity and ABTS radical scavenging activity.

\section{DPPH radical scavenging activity}

DPPH radical solution and different concentrations (12.5 to $200 \mu \mathrm{g} / \mathrm{ml}$ ) of leaf and fruit extracts and ascorbic acid (reference standard) were prepared in methanol. To each of the tubes containing $1 \mathrm{ml}$ of different concentrations of leaf and fruit extracts and ascorbic acid, $3 \mathrm{ml}$ of DPPH radical solution was added and the tubes were incubated in dark for $30 \mathrm{~min}$. The absorbance was measured in a spectrophotometer at $517 \mathrm{~nm}$. Extract replaced by methanol served as control. The radical scavenging potential of each concentration of extracts/ascorbic acid was determined using the formula:

$$
\text { Scavenging of DPPH Radicals }(\%)=\frac{(A-B)}{A} \times 100
$$

Where ' $\mathrm{A}$ ' and ' $\mathrm{B}$ ' denotes the absorbance of DPPH control and absorbance of DPPH in presence of extract/standard. The IC 50 value was calculated. $\mathrm{IC}_{50}$ value represents the concentration of extract required to scavenge $50 \%$ of DPPH radicals [24].

\section{ABTS radical scavenging activity}

ABTS radical was generated by mixing ABTS salt $(7 \mathrm{mmol})$ with Potassium persulfate $(2.45 \mathrm{mmol})$ and incubating for $16 \mathrm{~h}$. The resulting radical solution was diluted with distilled water to an absorbance 0.7 in spectrophotometer. $1 \mathrm{ml}$ of different concentrations $(12.5$ to $200 \mu \mathrm{g} / \mathrm{ml})$ of leaf and fruit extracts and ascorbic acid (reference standard) was mixed with $3 \mathrm{ml}$ of ABTS radical solution and the tubes were incubated in dark for $30 \mathrm{~min}$ at room temperature. The absorbance of reaction mixture of each tube was measured in a spectrophotometer at $730 \mathrm{~nm}$. Extract replaced by methanol served as control. The radical scavenging potential of each concentration of extracts/ascorbic acid was determined using the formula:

$$
\text { Scavenging of ABTS Radicals }(\%)=\frac{(A-B)}{A} \times 100
$$

Where ' $\mathrm{A}$ ' and 'B' represents the absorbance of ABTS control and absorbance of ABTS in presence of extract/standard. The IC ${ }_{50}$ value was calculated. $\mathrm{IC}_{50}$ value represents the concentration of extract required to scavenge $50 \%$ of ABTS radicals [24].

\section{Insecticidal activity of leaf and fruit extracts}

The insecticidal potential of leaf and fruit extracts in terms of larvicidal and pupicidal activity was assessed against $A$. aegypti. In brief, 20 larvae (II and IV instar) and pupae were transferred separately into conical flasks containing $50 \mathrm{ml}$ of water (with different concentrations of extracts namely 0.0 to $2.0 \mathrm{mg} / \mathrm{ml}$ ). The mortality of larvae and pupae (\%) was assessed after $24 \mathrm{~h}$ and was calculated using the formula:

$$
\text { Mortality (\%) }=\frac{\text { Number of Dead Larvae or Pupae }}{\text { Number of Total Larvae or Pupae }} \times 100
$$

$\mathrm{LC}_{50}$ value was calculated [26-27].

\section{Statistical analysis}

The experiments were conducted in triplicates and the results are presented as mean \pm Standard deviation (S. D). The $\mathrm{IC}_{50}$ and $\mathrm{LC}_{50}$ values were calculated by linear regression analysis using Origin (Data Analysis and Graphing) Software version 7.0 for windows.

\section{RESULTS AND DISCUSSION}

\section{Antibacterial activity of leaf and fruit extract of $G$. gummifera}

Emergence of antibiotic resistant strains of bacteria is of potential threat in hospital as well as community settings. Antibiotic resistant strains of bacteria such as Staphylococcus aureus, Pseudomonas aeruginosa, Escherichia coli and Mycobacterium tuberculosis are the main cause of death by infectious agents worldwide. Indiscriminate use of antibiotics and the ability of resistant strains of pathogens to transmit the resistance trait to susceptible strains by genetic means have made the situation even worst. Natural products are known to be an important alternate for the disease therapy. They are safer, cheaper and are not associated with side effects. Interest in botanicals with antibacterial activity has been triggered in recent years due to the drawbacks of antibiotics. Several studies have shown the potential of higher plants and their metabolites to inhibit pathogenic bacteria including antibiotic resistant strains [28-34]. In the present study, we determined the antibacterial potential of leaf and fruit extract of G. gummifera by Agar well diffusion method. This method has been extensively used to evaluate antibacterial activity of several plants and the presence of zone of inhibition around well is taken positive for antibacterial activity. The result of antibacterial activity of leaf and fruit extract is shown in table 1. Both extracts inhibited test bacteria as revealed by the absence of growth around the wells. Among extracts, marked activity was displayed by fruit 
extract when compared to leaf extract. S. epidermidis and E. coli were inhibited to highest and least extent by both extracts respectively. Inhibitory activity of antibiotic was higher when compared to leaf and fruit extracts. Overall, Gram positive bacteria were inhibited to higher extent than Gram negative bacteria by both extracts and antibiotic. DMSO did not cause inhibition of test bacteria. In an earlier study, Tambekar and Kante [8] found inhibitory activity of various solvent extracts of resin obtained from leaf buds and shoots of G. gummifera against S. aureus, Klebsiella pneumoniae and Enterobacter aerogenes. In another study, Narware et al. [17] showed the antibacterial potential of solvent extracts of gum of $G$. gummifera against $S$. aureus and E. coli. Other species of Gardenia such as G. volkensii [35], G. aqualla [36] and G. resinifera [37] have also shown antibacterial activity.

Table 1: Antibacterial activity of leaf and fruit extract of G. gummifera and antibiotic

\begin{tabular}{llll}
\hline Test bacteria & Zone of inhibition in mm (mean \pm SD $\mathbf{n = 3}$ ) & \\
\cline { 2 - 4 } & Leaf extract & Fruit extract & Antibiotic \\
\hline S. aureus & $12.67 \pm 0.58$ & $14.33 \pm 0.58$ & $33.00 \pm 1.00$ \\
S. epidermidis & $17.33 \pm 0.58$ & $19.33 \pm 0.58$ & $37.33 \pm 0.58$ \\
B. cereus & $14.00 \pm 0.00$ & $15.33 \pm 0.58$ & $36.00 \pm 0.00$ \\
B. subtilis & $15.00 \pm 0.00$ & $15.67 \pm 0.58$ & $33.00 \pm 1.00$ \\
P. aeruginosa & $11.67 \pm 0.58$ & $13.00 \pm 0.00$ & $27.67 \pm 0.58$ \\
E. coli & $11.00 \pm 0.00$ & $11.00 \pm 0.00$ & $25.33 \pm 0.58$ \\
S. typhimurium & $12.67 \pm 0.58$ & $13.67 \pm 0.58$ & $0.00 \pm 0.00$ \\
\hline
\end{tabular}

\section{Antifungal activity of leaf and fruit extract of G. gummifera}

Management of fungal pathogens by chemical agents is not much beneficial as they are costly, not easily degraded and implicated in environmental pollution. Besides, the development of resistance in fungal pathogens against the synthetic fungicides is another serious problem associated with their indiscriminate use. Plants and plant based formulations appear to be promising alternates for synthetic agents. Fungicides from botanical origin are safer, cheaper, easily degraded and do not cause environmental pollution. Several studies have shown the potential of plants and plant based formulations to inhibit a wide range of phytopathogenic fungi [38-44]. In the present study, we evaluated antifungal potential of leaf and fruit extract of $G$. gummifera by Poisoned food technique. This technique is one among the widely used antifungal assays in which reduction in the mycelial growth of test fungi on poisoned plates is taken positive for antifungal activity. Fruit extract of G. gummifera was found to exhibit higher antifungal effect when compared to leaf extract. Leaf extract exhibited highest and least inhibitory activity against $A$. niger and Fusarium sp. respectively. Fruit extract displayed highest and least inhibitory activity against $A$. flavus and Fusarium sp. respectively. Among test fungi, least susceptibility to extracts was shown by Fusarium sp. none of the fungi were inhibited to $>50 \%$ by leaf extract while $>50 \%$ inhibition by fruit extract was recorded against $A$. niger and $A$. flavus (table 2 and fig. 1). In an earlier study, Kafua et al. [45] showed the potential of leaf extract of $G$ brighamii to inhibit fumonisin producing Fusarium species. Genipin and geniposide isolated from $G$. jasminoides were shown to exhibit inhibitory activity against phytopathogenic fungi [46].

Table 2: Antifungal activity of leaf and fruit extract of G. gummifera

\begin{tabular}{llllll}
\hline Treatment & \multicolumn{2}{l}{ Colony diameter in mm (mean \pm SD $\mathbf{n}=3$ ) } & & \\
\cline { 2 - 6 } & A. niger & A. flavus & A. fumigatus & Curvularia sp. & Alternaria sp. \\
\hline Control & $56.67 \pm 0.58$ & $43.00 \pm 0.00$ & $38.67 \pm 1.53$ & $45.33 \pm 0.58$ & $52.00 \pm 1.00$ \\
Leaf extract & $29.00 \pm 0.00$ & $29.67 \pm 0.58$ & $26.00 \pm 0.00$ & $32.00 \pm 1.00$ & $38.00 \pm 0.00$ \\
Fruit extract & $27.67 \pm 0.58$ & $20.00 \pm 0.00$ & $23.67 \pm 0.58$ & $22.67 \pm 0.58$ & $35.33 \pm 1.15$ \\
\hline
\end{tabular}

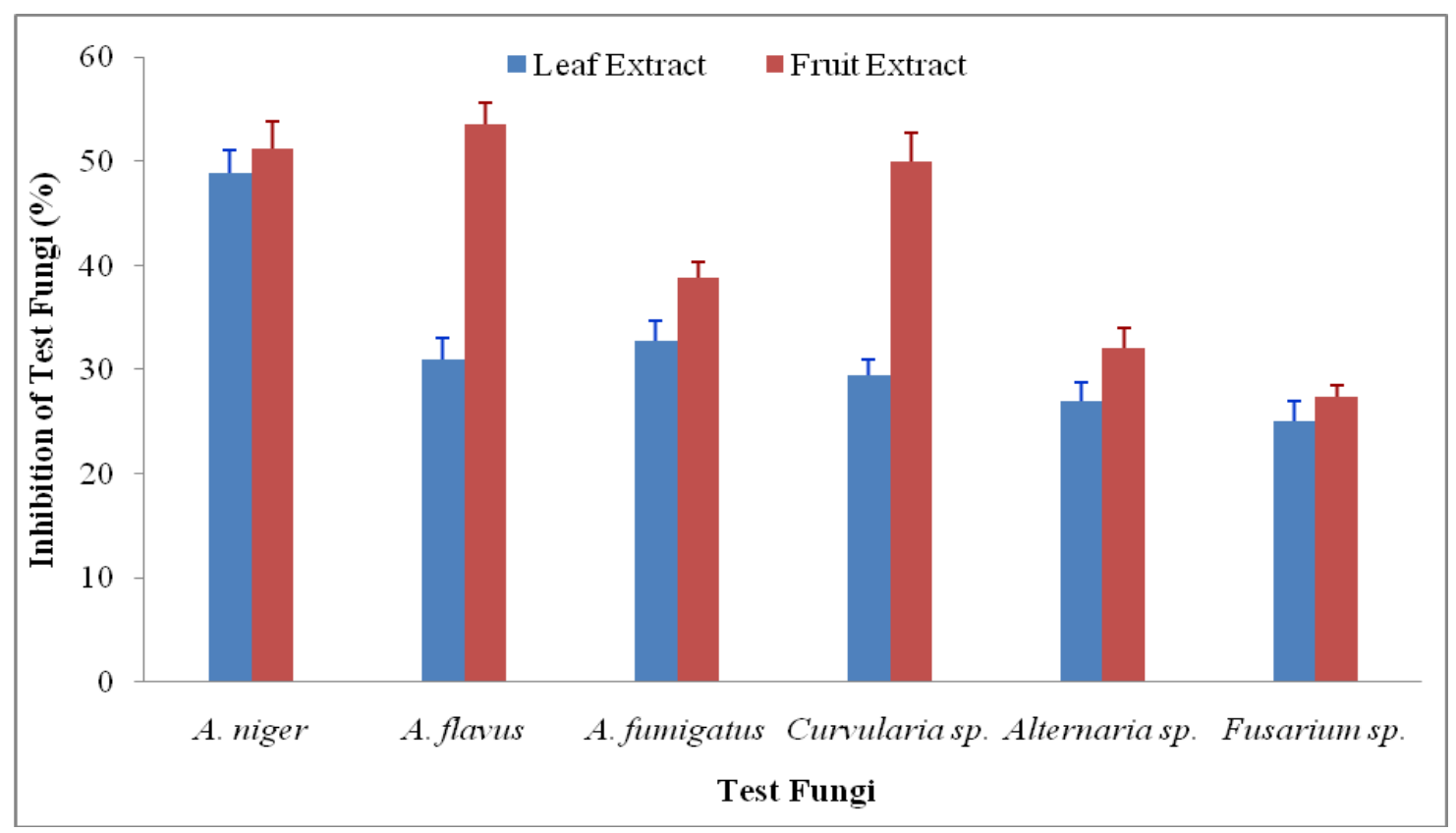

Fig. 1: Extent of inhibition of test fungi (\%) by leaf and fruit extract 


\section{Antiradical activity of leaf and fruit extract of G. gummifera}

Free radicals are produced during normal metabolism of oxygen and some cell mediated immune functions of the body. There exists a dynamic balance between free radical generation and antioxidant defense (enzymatic and non-enzymatic) of the body. However, when the excessive generation of free radicals occur it result in oxidative stress which is implicated in several diseases or conditions such as Diabetes, Atherosclerosis, Alzheimer's disease, Parkinsonism, Cardiovascular diseases, Inflammatory conditions, Neonatal diseases, Cancer and Aging. Free radicals are compounds with one or more unpaired electrons and are known to damage biomolecules such as nucleic acid, proteins and lipids. Antioxidants are substances capable of inhibiting or delaying oxidative damage when present in small quantities compared to an oxidizable substrate.

Antioxidants act by effective quenching free radicals or inhibiting damage caused by them. In pathophysiological conditions, there is an extra need for antioxidants from exogenous sources. Interest in botanicals as antioxidants has emerged due to suspected negative effects that are associated with the use of synthetic antioxidants such BHA, BHT etc. many plant species have been shown to possess marked antioxidant activity which is attributed to the presence of phytochemicals mainly phenolic compounds [31, 47-55].

Among various in vitro radical scavenging assays, the assay involving scavenging of DPPH radicals is one of the widely used assays. The method is simple, rapid, does not generation of radicals and the results can be reproducible. DPPH radical is a stable, organic nitrogen centered free radical having purple color and an absorption maximum at $517 \mathrm{~nm}$ in alcoholic solution. On accepting a proton from a donor (an antioxidant), the DPPH loses the free radical nature and gets converted into a corresponding yellow colored hydrazine i.e., DPPHH and the extent of bleaching of purple color depends on proton donating ability of sample. The assay has been employed by various researchers to evaluate radical scavenging potential of various kinds of samples including plant extracts and plant metabolites $[24,33,53,56-63]$. In this study, we evaluated the potential of leaf and fruit extract of G. gummifera by DPPH assay and the result is shown in fig. 2 . Both extracts and ascorbic acid exhibited concentration dependent scavenging of DPPH radicals. Among extracts, the fruit extract scavenged DPPH radicals to higher extent with an IC $_{50}$ value of $2.53 \mu \mathrm{g} / \mathrm{ml}$ when compared to leaf extract (IC 50 $49.01 \mu \mathrm{g} / \mathrm{ml}$ ). At concentration $25 \mu \mathrm{g} / \mathrm{ml}$, fruit extract exhibited a scavenging activity of $>50 \%$ while leaf extract displayed $>50 \%$ scavenging of radicals at $50 \mu \mathrm{g} / \mathrm{ml}$ concentration. A scavenging activity of $>90 \%$ was shown by both leaf and fruit extracts at concentration $200 \mu \mathrm{g} / \mathrm{ml}$. Ascorbic acid scavenged radicals with an $\mathrm{IC}_{50}$ value of $10.19 \mu \mathrm{g} / \mathrm{ml}$. In an earlier study, Vindhya and Leelavathi [16] showed DPPH radical scavenging activity of various solvent extracts of leaf of $G$. gummifera. Ethanol extract exhibited marked scavenging of DPPH radicals with an $\mathrm{IC}_{50}$ value of $48.33 \mu \mathrm{g} / \mathrm{ml}$.

The study of Uddin et al. [53] showed significant scavenging of DPPH radicals by leaf extract of $G$. jasminoides. Debnath et al. [52] showed the DPPH radical scavenging efficacy of aqueous and ethanolic extract of fruits of $G$. jasminoides. Leaf extracts of $G$. latifolia have shown scavenging potential against DPPH radicals [64].

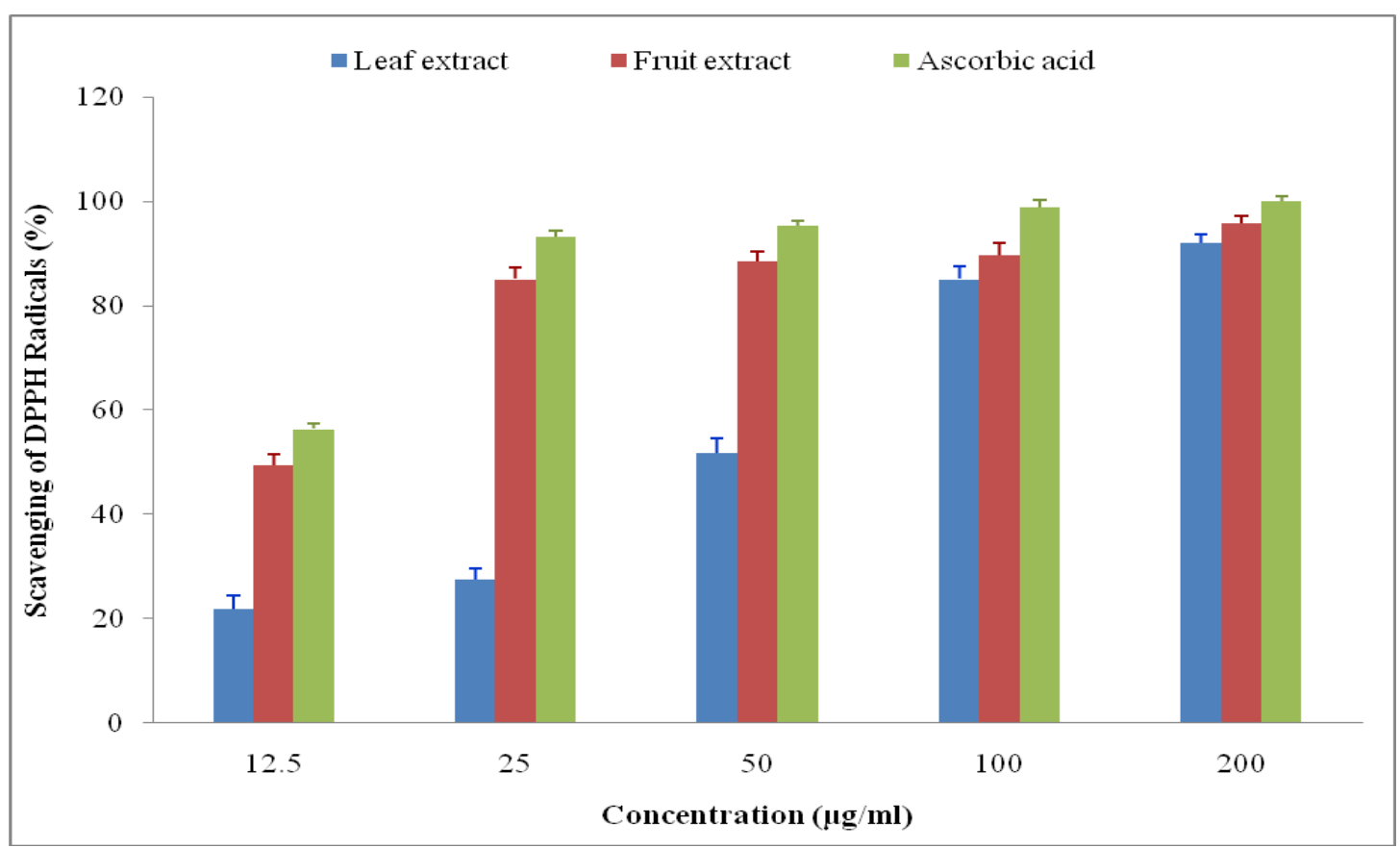

Fig. 2: Scavenging of DPPH radicals by leaf and fruit extract of G. gummifera

ABTS radical scavenging assay is another widely used in vitro radical assay. It differs from DPPH assay in that it needs the generation of radicals prior to assay. The generation of ABTS radicals can be carried out by mixing ABTS salt with an oxidizing agent such as potassium persulfate or potassium permanganate. Substances with electronic donating potential (antioxidant species) will reduce the blue-green colored radical solution to colorless neutral form which is shown by the suppression of characteristic long wavelength absorption spectrum. The method of scavenging of ABTS radicals has been extensively used to evaluate radical scavenging nature of plant extracts $[24,52,58,61$, $62,65,66]$. In the present study, we evaluated radical scavenging nature of leaf and fruit extract of G. gummifera by ABTS assay and the result is shown in fig. 3. Both the extracts and ascorbic acid displayed concentration dependent scavenging of ABTS radicals. All concentrations of extracts displayed $>75 \%$ scavenging of radicals. At $100 \mu \mathrm{g} / \mathrm{ml}$, only fruit extract showed $>90 \%$ scavenging of radicals. Among extracts, fruit extract exhibited marked scavenging of ABTS radicals with (an $\mathrm{IC}_{50}$ value of $2.31 \mu \mathrm{g} / \mathrm{ml}$ ) when compared to leaf extract ( $\mathrm{IC}_{50}$ value of $2.58 \mu \mathrm{g} / \mathrm{ml}$ ). Ascorbic acid displayed marked scavenging of ABTS radicals (IC 50 value of $1.64 \mu \mathrm{g} / \mathrm{ml}$ ) when compared to leaf and fruit extracts. In an earlier study, aqueous and ethanolic extract of $G$. jasminoides fruit exhibited marked scavenging potential against ABTS radicals [52]. A water soluble polysaccharide isolated from $G$. jasminoides was shown to exhibit dose dependent scavenging of ABTS radicals [67]. 


\section{Insecticidal activity of leaf and fruit extract of G. gummifera}

Mosquitoes are considered as the major public health problem worldwide as the mosquitoes are well known as vectors of transmission of various human diseases such as malaria, filariasis, dengue, chikungunya, Japanese encephalitis and yellow fever. Species of Culex, Aedes and Anopheles are more important mosquito genera as they transmit dreadful human diseases. Filariasis is transmitted by Culex quinquefasciatus, malaria is transmitted by female Anopheles mosquito and diseases such as chikungunya and dengue are transmitted by Aedes aegypti. It is very important to prevent and control mosquitoes in order to achieve control of mosquito-borne diseases. Several stages in the life cycle of mosquitoes are targeted in order to prevent mosquitoborne diseases. Strategies such as prevention of egg hatching, killing of larvae, pupae and adult mosquitoes and use of mosquito repellents have been used for controlling mosquitoes. Synthetic insecticides are being used extensively, however, their use is associated with several drawbacks. The use of botanicals offers a safer and cheaper strategy for mosquito control. It is shown that plants, plant based formulations and plant metabolites exhibit insecticidal activity against several mosquitoes such as species of Aedes, Culex and Anopheles [26, 27, 68-75].

In the present study we evaluated insecticidal activity of various concentrations of leaf and fruit extract of $G$. gummifera against larvae and pupae of $A$. aegypti. The extracts were effective in killing larvae and pupae in a concentration dependent manner (fig. 4 and 5). The susceptibility of larvae and pupae to extracts was in the order: II instar larvae>IV instar larvae>pupae. Fruit extract exhibited marked insecticidal activity when compared to leaf extract. The LC50 of leaf extract against II instar larvae, IV instar larvae and pupae was found to be $0.5,1.5$ and $2.5 \mathrm{mg} / \mathrm{ml}$ respectively. The LC50 of fruit extract was $0.42,1.0$ and 1.94 $\mathrm{mg} / \mathrm{ml}$ for II instar larvae, IV instar larvae and pupae respectively. In an earlier study, the ethanolic extract of dried exudates from $G$. gummifera was shown to exhibit dose dependent larvicidal activity against Culex quinquefasciatus [18].

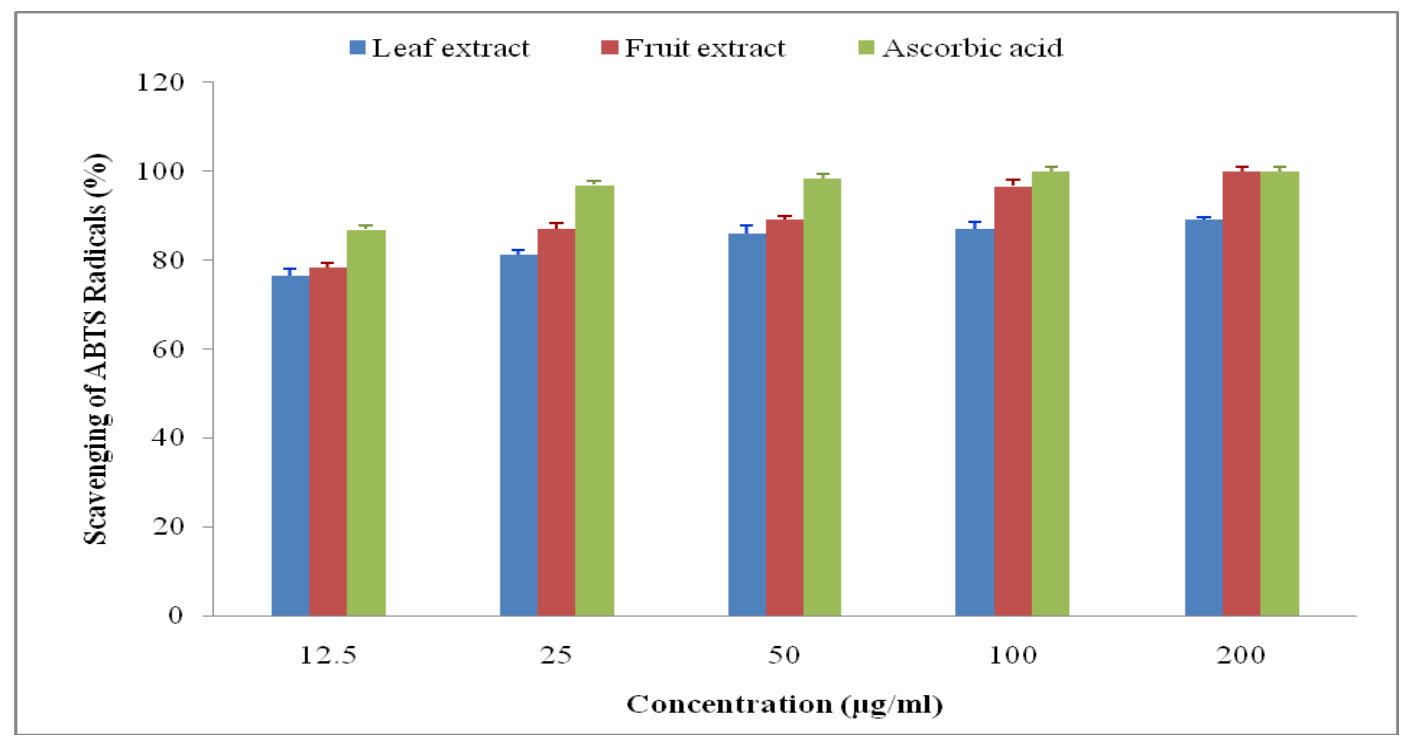

Fig. 3: Scavenging of ABTS radicals by leaf and fruit extract of $G$. gummifera

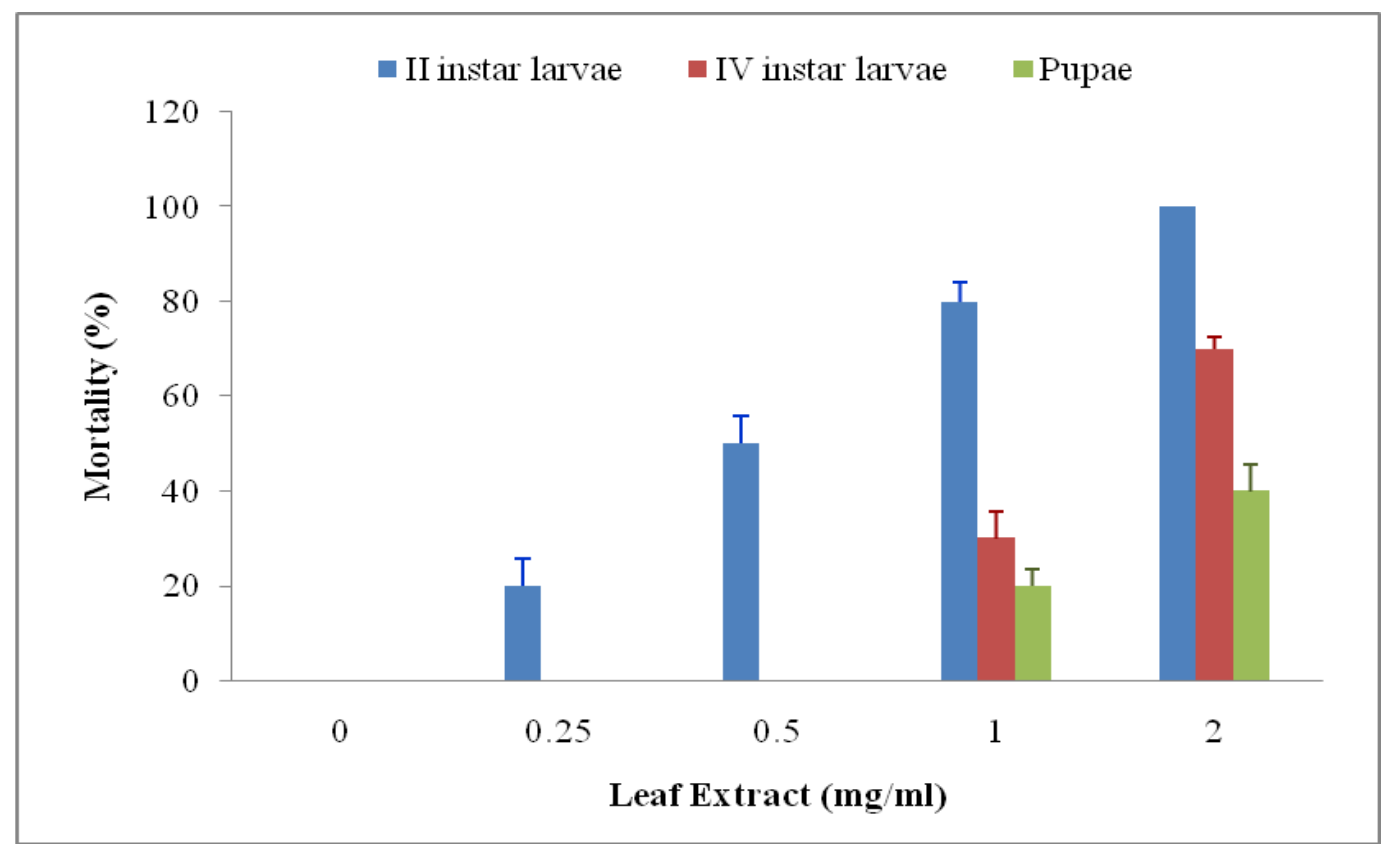

Fig. 4: Mortality of larvae and pupae at different concentrations of leaf extract 


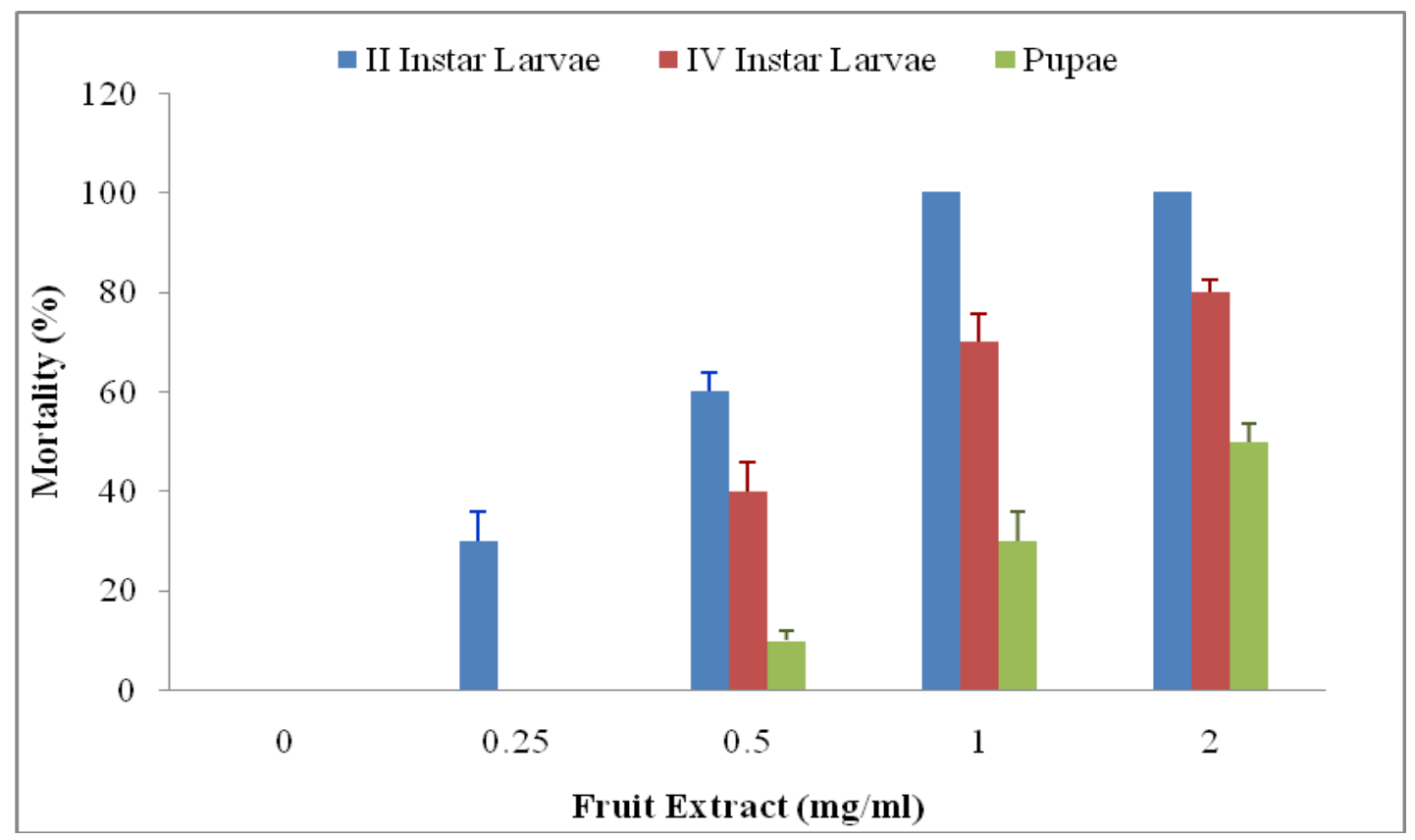

Fig. 5: Mortality of larvae and pupae at different concentrations of fruit extract

\section{CONCLUSION}

The present study has shown promising antimicrobial, antiradical and insecticidal activity of leaf and fruit of G. gummifera. Overall, fruit extract was found to exhibit higher antimicrobial, antiradical and insecticidal activity when compared to leaf extract. The observed bioactivities could be ascribed to the presence of phytochemicals in extracts. In suitable form, the plant can be used to treat infectious diseases, oxidative stress and to control phytopathogenic fungi and insect vectors.

\section{ACKNOWLEDGEMENT}

Authors thank Head of the Department of Microbiology and Principal of S. R. N. M. N College of Applied Sciences for providing facilities to conduct work. Authors express sincere thanks to N. E. S for moral support. Authors also thank Dr. Vinayaka, K. S, KFGC, Shikaripura for helping in collection and identification of plant material.

\section{AUTHORS CONTRIBUTION}

The author Prashith was involved in the collection of plant material and all the bioactivities conducted in the study. Prashith and Raghavendra have planned and framed the objectives. Shilpa, Pushpavathi, Petkar and Siddiqha contributed equally for carrying out extraction and antimicrobial and antiradical activity. Insecticidal activity and statistical analysis was carried out by Prashith and Raghavendra. Furthermore, Prashith and Raghavendra wrote the draft paper and the final paper was corrected and approved by all authors.

\section{CONFLICT OF INTERESTS}

Authors declared that there are no potential conflicts of interest

\section{REFERENCES}

1. Parmar VS, Sharma SK, Poonam. Novel constituents of Gardenia species-a review. J Sci Indian Res 2000;59:893-903.

2. Ramabharathi V, Rao AVNA, Rajitha G. Phytochemical investigation and evaluation of antibacterial and antioxidant activities of leaf-bud exudate of Tarenna asiatica (L.) Kuntze ex K. Schum. Indian J Nat Prod Resour 2014;5:48-51.

3. Khare CP. Indian herbal remedies: rational western therapy, Ayurvedic and other traditional usage, Botany. Springer-Verlag, Berlin; 2004.

4. Bhat GK. Flora of South Kanara. Akriti Prints, Mangalore, India; 2014.
5. Patwari SG, Harikiran L, Rao AAVN, Reddy NY. Evaluation of anticancer activity of dikamaliartane-a, a cycloartane isolated from dikamali, a gum resin. Int J Pharm Pharm Sci 2012;4:501-4.

6. Manjunatha BK, Krishna V, Pullaiah T. Flora of davanagere district, Karnataka, India. Regency Publications, New Delhi, India; 2004.

7. Prasad MNV, Padmalatha K, Jayaram K, Raju NL, da Silva JAT. Medicinal plants from Deccan ecoregion, India: Traditional knowledge, ethnopharmacology, cultivation, utilization, conservation and biotechnology-opportunities and impediments. Med Aromatic Plant Sci Biotechnol 2007;1:155-208.

8. Tambekar DH, Khante BS. Antibacterial evaluation of medicinal plants used by Korkus in Melghat forest against gastrointestinal infections. Int J Pharm Sci Res 2011;2:577-83.

9. Shanmugam S, Annadurai M, Rajendran K. Ethnomedicinal plants used to cure diarrhea and dysentery in Pachalur hills of Dindigul district in Tamil Nadu, Southern India. J Appl Pharm Sci 2011;1:94-7.

10. Sammaiah D, Chandraiah G, Devi AU, Rajesham KC, Ugandhar T. Progress and prospects of medicinal plants of ethnopediatric importance in mahadevapur reserve forest of Karimnagar East division of (A. P.) India. Biosci Discovery 2013;4:173-5.

11. Savithramma N, Yugandhar P, Babu HR, Prasad SK. Validation of indigenous knowledge of Yanadi tribe and local villagers of Veyilingalakona-A sacred grove of Andhra Pradesh, India. J Pharm Sci Res 2014;6:382-8.

12. Maitreya BB. An overview of ethnomedicinal plants of family rubiaceae from sabarmati river of Gujarat state, India. Int J Pharm Life Sci 2015;6:4476-80.

13. Shiddamallayya N, Rao RV, Venkateshwarlu G, Giri SK, Doddamani SH. Traditional local health practices of Haveri, Karnataka. Unique J Ayurvedic Herbal Med 2015;3:135-45.

14. Sridhar SK, Ramachandran S, Anbalagan N, Leonard TJ, Joanofarc J, Kumar SS. Pharmacological screening of dikamali resin extract. Nat Prod Sci 2003;9:10-2.

15. Sabbani PK, Chityala PK, Gowrishankar NL, Kumar NG, Shilpa K, Tejaswi $\mathrm{CH}$. Evaluation of antioxidant and antiulcer activity of methanolic extract of Gardenia gummifera L. in rats. Asian J Pharm Clin Res 2015;8:41-4.

16. Vindhya K, Leelavathi S. Evaluation of antioxidant properties and total phenolic content of Gardenia gummifera Linn. Int J Pharm Sci Rev Res 2015;32:255-61.

17. Narware N, Mishra PK, Shrivastava PN. Preliminary phytochemical study and antimicrobial activity of the gum 
extracts of Gardenia gummifera Linn. Int J Green Herb Chem 2014;3:717-21.

18. Suryadeva P, Khanam S. Screening of plant extracts for larvicidal activity against Culex quinquefasciatus. J Nat Rem 2002;2:186-8.

19. Vindhya K, Leelavathi S. In vitro cytotoxic activities of leaf extract of Gardenia latifolia Ait. and Gardenia gummifera Linn. Int J Pharm Sci Res 2014;5:4975-8.

20. Sabbani PK, Thatipelli RC, Surampalli G, Duvvala P. Evaluation of hepatoprotective activity with different fractions of Gardenia gummifera Linn. on paracetamol induced liver damage in rats. J Drug Metab Toxicol 2016;7:1.

21. Pal CR, Garge VN, Kadam VJ. Antihyperlipidemic activity of Gardenia gummifera. J Med Sci Clin Res 2015;3:5000-10.

22. Prabha SP, Ansil PN, Nitha A, Wills PJ, Latha MS. Antiatherogenic activity of methanolic extract of Gardenia gummifera Linn. F. on high fat diet induced atherosclerosis in rats. Int J Pharm Pharm Sci 2013;5:388-93.

23. Prabha SP, Nitha A, Ansil PN, Latha MS. Cardioprotective effect of methanolic extract of Gardenia gummifera Linn. F. on isoproterenol induced myocardial infarction in rats. Int J Pharm Sci Res 2014;5:3817-28.

24. Kekuda PTR, Raghavendra HL, Solomon T, Duressa D. Antifungal and antiradical potential of Moringa stenopetala (Baker f.) Cufod (Moringaceae). J Biosci Agric Res 2016;11:923-9.

25. Raghavendra HL, Kekuda PTR, Vijayananda BN, Duressa D, Solomon T. Nutritive composition and antimicrobial activity of Moringa stenopetala (Baker f.) Cufod. J Adv Med Pharm Sci 2016:10:1-9.

26. Kaushik R, Saini P. Screening of some semi-arid region plants for larvicidal activity against Aedes aegypti mosquitoes. J Vector Borne Dis 2009;46:244-6.

27. Selvaraj M, Mosses M. Efficacy of melia azedarach on the larvae of three mosquito species Anopheles stephensi, Culex quinquefasciatus and Aedes aegypti (Diptera: Culicidae). Eur Mosquito Bull 2011;29:116-21.

28. Cowan MM. Plant products as antimicrobial agents. Clin Microbiol Rev 1999;12:564-82.

29. Sibanda T, Okoh AI. The challenges of overcoming antibiotic resistance: Plant extracts as potential sources of antimicrobial and resistance modifying agents. Afr J Biotechnol 2007;6:2886-96.

30. Abdullah EM. Plants: an alternative source for antimicrobials. J Appl Pharm Sci 2011;1:16-20.

31. Kekuda PTR, Rakesh KN, Dileep N, Junaid S, Pavithra GM, Gunaga SS, et al. Antimicrobial and antioxidant activity of Anaphalis lawii (Hook. f.) Gamble. Sci Technol Arts Res J 2012;1:8-16.

32. Al-Mariri A, Safi M. In vitro antibacterial activity of several plant extracts and oils against some gram-negative bacteria. Iranian J Med Sci 2014;39:36-43.

33. Kekuda PTR, Siddiqha A, Pushpavathi D, Vinayaka KS, Raghavendra HL. Radical scavenging, cytotoxic and antimicrobial activity of Flacourtia indica (Burm. f.) Merr. Med Health Sci Res J 2017;1:76-82.

34. Fankam AG, Kuiate JR, Kuete V. Antibacterial and antibiotic resistance modulatory activities of leaves and bark extracts of Recinodindron heudelotii (Euphorbiaceae) against multidrugresistant gram-negative bacteria. BMC Complementary Altern Med 2017;17:168.

35. Wanjiru KE, Mwangi EM, Cheplogoi PK. Screening for antimicrobial compounds in Gardenia volkensii fruits (Rubiaceae). Int J Sci Eng Res 2013;4:1253-6.

36. Njinga NS, Sule MI, Pateh UU, Hassan HS, Usman MA, Bilkisu A, et al. Phytochemical and antimicrobial activity of the stem-bark of Gardenia aqualla Stapf and Hutch (Rubeacea). J Med Plant Res 2014;8:942-6.

37. Gaurea SH, Bapat UC. Study of antibacterial activity of resins of Boswellia serrata Roxb Ex Colebr., Commiphora mukul (Hooks Ex-stocks) Engl, Gardenia resinifera Roth. and Shorea robusta Gaertn. Int J Pharm Pharm Sci 2016;8(S1):29-31.

38. Yazdani D, Tan YH, Abidin ZMA, Jaganath IB. A review on bioactive compounds isolated from plants against plant pathogenic fungi. J Med Plants Res 2011;5:6584-9.
39. Rongai D, Milano E, Sciò E. Inhibitory effect of plant extracts on conidial germination of the phytopathogenic fungus Fusarium oxysporum. Am J Plant Sci 2012;3:1693-8.

40. Gaikwad RS, Kakde RB, Kulkarni AU, Gaikwad DR, Panchal VH. In vitro antimicrobial activity of crude extracts of Jatropha species. Curr Bot 2012;3:9-15.

41. Masangwa JIG, Aveling TAS, Kritzinger Q. Screening of plant extracts for antifungal activities against Colletotrichum species of common bean (Phaseolus vulgaris L.) and cowpea (Vigna unguiculata (L.) Walp). J Agric Sci 2013;151:482-91.

42. Chandra M, Mahesh NM. Antifungal activity of medicinal plant extracts against seed-borne pathogenic fungi. Acta Biologica Indica 2013;2:481-3.

43. Parveen S, Wani AH, Ganie AA, Pala SA, Mir RA. Antifungal activity of some plant extracts on some pathogenic fungi. Arch Phytopathol Plant Prot 2014;47:279-84.

44. Yazgi M, Awad D, Jreikous B. Screening of the antifungal activity of plant Mentha longifolia crude extracts against two fungi Alternaria citri and Fusarium moniliforme. J Entomol Zool Stud 2015;3:359-64.

45. Kafua L, Kritzinger Q, Hussein AA. Antifungal activity of Gardenia brighamii leaf extracts. South Afr J Bot 2010;76:411.

46. Lelono RA, Tachibana $\mathrm{S}$, Itoh $\mathrm{K}$. Isolation of antifungal compounds from Gardenia jasminoides. Pak J Biol Sci 2009;12:949-56

47. Chatterjee S, Poduval TB, Tilak JC, Devasagayam TPA. A modified, economic, sensitive method for measuring total antioxidant capacities of human plasma and natural compounds using Indian saffron (Crocus sativus). Clin Chim Acta 2005;352:155-63.

48. Shirwaikar A, Prabhu KS, Punitha ISR. In vitro antioxidant studies of Sphaeranthus indicus (Linn). Indian J Exp Biol 2006;44:993-6.

49. Bhutia RD, Upadhyay B, Maneesh M. Association of plasma level of thiobarbituric acid reactive substances with extent of hepatocellular injury in preterm infants with cholestatic jaundice. Indian J Clin Biochem 2006;21:39-41.

50. Choi Y, Jeong H, Lee J. Antioxidant activity of methanolic extracts from some grains consumed in Korea. Food Chem 2007;103:130-8.

51. Hazra B, Biswas S, Mandal N. Antioxidant and free radical scavenging activity of Spondias pinnata. BMC Complementary Altern Med 2008;8:63.

52. Debnath T, Park P, DebNath NC, Samad NB, Park HW, Lim BO. Antioxidant activity of Gardenia jasminoides Ellis fruit extracts. Food Chem 2011;128:697-703.

53. Uddin R, Saha MR, Subhan N, Hossain H, Jahan IA, Akter R, et al. HPLC-analysis of polyphenolic compounds in Gardenia jasminoides and determination of antioxidant activity by using free radical scavenging assays. Adv Pharm Bull 2014;4:273-81.

54. Sayari N, Saidi MN, Sila A, Ellourz-chaabouni S, Bougatef A. Chemical composition, angiotensin I-converting enzyme (ACE) inhibitory, antioxydant and antimicrobial activities of Ononis natrix leaves extracts. Free Radicals Antioxid 2016;6:23-33.

55. Urquiza-Martínez MV, Navarro BF. Antioxidant capacity of food. Free Radicals Antioxid 2016;6:1-12.

56. Molyneux P. The use of the stable free radical diphenylpicrylhydrazyl (DPPH) for estimating antioxidant activity. Songklanakarin J Sci Technol 2004;26:211-9.

57. Chung Y, Chien C, Teng K, Chou S. Antioxidative and mutagenic properties of Zanthoxylum ailanthoides Sieb and zucc. Food Chem 2006;97:418-25.

58. Krishna MS, Nair JA. Antibacterial, cytotoxic and antioxidant potential of different extracts from leaf, bark and wood of Tectona grandis. Int J Pharm Sci Drug Res 2010;2:155-8.

59. Menon DB, Sasikumar JM, Latha K. Phytochemical analysis and antioxidant activity of methanolic extract of Plectranthus hadiensis (Forssk.) Schweinf. ex Spreng. aerial parts. Indian J Nat Prod Resour 2012;3:359-65.

60. Pazhanisamy M, Ebenezer GAI. Antioxidant activity of leaves of an important medicinal plant Ormocarpum cochinchinense (Lour.) Merr. J Modern Biotechnol 2013;2:89-94.

61. Fidrianny I, Rahmiyani I, Wirasutisna KR. Antioxidant capacities from various leaves extracts of four varieties mangoes using DPPH, ABTS assays and correlation with total phenolic, flavonoid, carotenoid. Int J Pharm Pharm Sci 2013;5:189-94. 
62. Shalaby EA, Shanab SMM. Comparison of DPPH and ABTS assays for determining antioxidant potential of water and methanol extracts of Spirulina platensis. Indian J Geo-Mar Sci 2013;42:556-64.

63. Ajileye 00, Obuotor EM, Akinkunmi EO, Aderogba MA. Isolation and characterization of antioxidant and antimicrobial compounds from Anacardium occidentale L. (Anacardiaceae) leaf extract. J King Saud Univ Sci 2015;27:244-52.

64. Vindhya K, Kumar PPM, Roopa AR, Leelavathi S. Evaluation of in vitro antioxidant potential of various leaf extracts of Gardenia latifolia Ait. Int J Innovative Pharm Sci Res 2015;3:176-90.

65. Thaipong $\mathrm{K}$, Boonprakob U, Crosby K, Cisneros-Zevallos $\mathrm{L}$, Byrne DH. Comparison of ABTS, DPPH, FRAP, and ORAC assays for estimating antioxidant activity from guava fruit extracts. J Food Compos Anal 2006;19:669-75.

66. Rajurkar NS, Hande SM. Estimation of phytochemical content and antioxidant activity of some selected traditional Indian medicinal plants. Indian J Pharm Sci 2011;73:146-51.

67. Fan Y, Ge Z, Luo A. In vitro antioxidant activity of polysaccharide from Gardenia jasminoides Ellis. J Med Plants Res 2011;5:2963-8.

68. Katyal R, Tewari P, Rahman SJ, Pajni HR, Kumar K, Gill KS. Susceptibility status of immature and adult stages of Aedes aegypti against conventional insecticides in Delhi, India. Dengue Bull 2001;25:84-7.

69. Promsiri S, Naksathit A, Kruatrachue M, Thavara U. Evaluations of larvicidal activity of medicinal plant extracts to Aedes aegypti (Diptera: Culicidae) and other effects on a non target fish. Insect Sci 2006;13:179-88.

70. Elimam AM, Elmalik KH, Ali FS. Efficacy of leaves extract of Calotropis procera Ait. (Asclepiadaceae) in controlling
Anopheles arabiensis and Culex quinquefasciatus mosquitoes. Saudi J Biol Sci 2009;16:95-100.

71. Phukerd U, Soonwera M. Larvicidal and pupicidal activities of essential oils from Zingiberaceae plants against Aedes aegypti (Linn.) and Culex quinquefasciatus say mosquitoes. Southeast Asian J Trop Med Pub Health 2013;44:761-71.

72. Panneerselvam C, Murugan K, Kovendan K, Kumar PM, Subramaniam J. Mosquito larvicidal and pupicidal activity of Euphorbia hirta Linn. (Family: Euphorbiaceae) and Bacillus sphaericus against Anopheles stephensi Liston. (Diptera: Culicidae). Asian Pac J Trop Med 2013;6:102-9.

73. Valentina J, Poonguzhali TV, Nisha JLLL. Mosquito larvicida and pupicidal activity of seaweed extracts against Aedes aegypti, Anopheles stephensi and Culex quinquefasciatus. Int J Mosquito Res 2015;2:54-9.

74. Nwankwo EN, Okonkwo NJ, Ogbonna CU, Akpom CJO, Egbuche CM, Ukonze BC. Moringa oleifera and Annona muricata seed oil extracts as biopesticides against the second and fourth larval instar of Aedes aegypti L. (Diptera: Culicidae). J Biopestic 2015;8:56-61.

75. El-Bokl MM. Toxicity and bioefficacy of selected plant extracts against the mosquito vector Culex pipiens L. (Diptera: Culicidae). J Entomol Zool Stud 2016;4:483-8.

\section{How to cite this article}

- $\quad$ Prashith Kekuda TR, Raghavendra HL, Shilpa M, Pushpavathi D, Tejaswini Petkar, Ayesha Siddiqha. Antimicrobial, antiradical and insecticidal activity of Gardenia gummifera L. F. (Rubiaceae). Int J Pharm Pharm Sci 2017;9(10):265-272. 